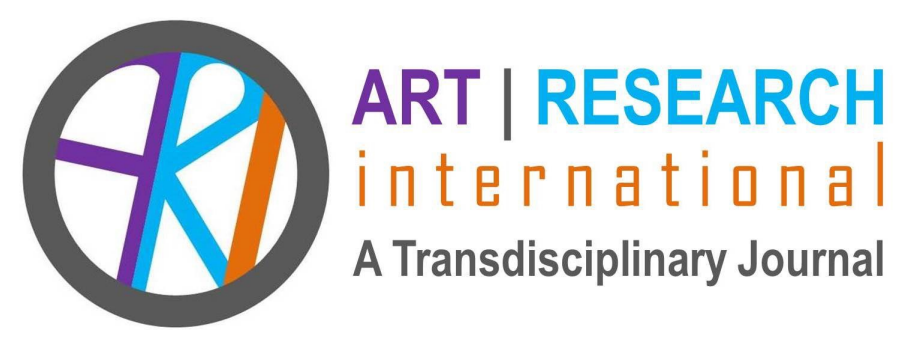

\title{
TILLING THE GARDEN OF JOYISORROW: A POETIC INQUIRY INTO THE RHIZOMATIC COMPLEXITIES OF GROWING INTO AND THROUGH COLLECTIVE SPACES
}

Joanna Szabo
Mount Royal University
iszabohart@mtroyal.ca

Bev Mathison

Mount Royal University blmathison@mtroyal.ca

Sonya L. Jakubec Mount Royal University sjakubec@mtroyal.ca

Sonya Flessati Mount Royal University sflessati@mtroyal.ca

Genevieve Currie Mount Royal University gcurrie@mtroyal.ca

Joanna Szabo, RN, PhD, is an Associate Professor in the School of Nursing and Midwifery at Mount Royal University in Calgary, Alberta, Canada. Joanna considers herself a collectively-minded inquirer and her work explores reflective practice, relational ethics, ecohealth and complexity thinking in healthcare and community contexts. Coming from a pediatric and critical care nursing background, she is currently using poetic inquiry and methods to explore parents' experience of having a child with a rare disease. 
Bev Mathison is an Associate Professor in the Department of Child Studies \& Social Work at Mount Royal University in Calgary, Alberta, Canada. As a former public school teacher and faculty member in a Department of Education, her pedagogical focus rests within an inquiry-based approach to teaching and learning. Her way of being is owed to her interests in ecological mindedness, a strong recognition of the interconnectedness of all beings and non-beings, interpretive studies, and the role of contemplative practice in work and life. She is currently embarking on a study of flourishing in the academy.

Sonya L. Jakubec, PhD, RN, is an Associate Professor in the School of Nursing and Midwifery at Mount Royal University in Calgary, Alberta, Canada. A community mental health nurse and community-engaged researcher, her work explores the connection of lifespan health/wellbeing and physical, social and political environments. She is currently studying the place of parks and nature in palliative and grief care.

Sonya Flessati, PhD, RPsych is an Associate Professor and Psychologist in Student Counselling Services at Mount Royal University in Calgary, Alberta, Canada. Her practice is focused on the use of strength-based approaches in the promotion of resilience, mental and physical health. She is currently exploring the impact of mindfulness on the well-being of students.

Genevieve Currie, RN, MN, is an Associate Professor in the School of Nursing and Midwifery at Mount Royal University in Calgary, Alberta, Canada. Her background is pediatric nursing, community health, and family health. She is currently exploring the parents' experience of having a child with a rare disease.

Abstract: A pilot research project turned ongoing program sought to explore the experience of participating in an inclusive Campus Community Garden. In the confines of institutional research the project undertook a specific focus on uncovering the perceived benefits and barriers to participating preschoolers, older adults, individuals with mixed abilities and their caregivers from residential and intermediate care facilities. This paper describes a parallel exploration as an occurrent act of art making; an evolving rhizomatic process of poetic reflection on images and privileged notes from the field. In this work, the authors uncover the shape, movement, and colour of the joy/ sorrow of tilling the garden through creative expression.

Keywords: rhizomatic complexity, poetic inquiry, campus community garden 
Somewhere in the space between reading philosophy alongside notes from the field and organizing photographic images of time in our campus community garden, this representation/restorying and remembering of moments emerged. In this paper, we, a blend of serious researchers, passionate gardeners, and fondest friends, aim to share our journey into community growth, provoking, invoking and evoking a sentient research study into wakefulness and awareness using poetry and photographic images. This paper offers a rendering of a participatory community gardening and horticultural therapy research project (Jakubec, et al., forthcoming) that originated in an inclusive community-university garden site. The field notes from our project provoke the experiences from our tilling/toiling when read within a theoretical landscape as a "relational-qualitative duplicity" (Massumi, 2011, p. 5). Massumi suggested this duplicity is at the heart of an activist philosophy, which differentiates an emergent force between gatherings. For us, poetic reflecting invokes aliveness, breath, movement and breathing through the text with an evocative quality of cocomposting/composing in the garden.

Our collaborative, creative process enabled a movement to deconstruct the strictures of academic texts, research reports and accounts that could never fully satisfy the sensory experience of a project set in the enlivening decay of a garden. This process extended from a participatory research project investigating the experiences of garden participants (older adults from neighbouring residential care and assisted living facilities, university students, preschool-aged children from the university child care centre, as well as assorted volunteers and visitors to the site). This project occurred over the course of two growing seasons, 2016 and 2017, on the garden site of an urban university community garden.

By the close of our paper, through the acts of tilling and toiling, we aim to liberate, aerate, and shake loose the written form in its distinctions (explicating the entanglement and disentanglement of how words on the page inform and de-form the text to distinguish and connect the observer/ed). This blurring and blending of voices introduces a departure or flight from the dominant territories (Deleuze \& Guittari, 1987) that challenge the power and responsiveness of texture, as an ethical move (p. 106). The rhizomatic complexity of this act/art grounds and foregrounds several questions: Whose voices get sifted through the sediment that remains? Who benefits from the shaking of rooted foundations? How does an activist occurrence hold a semblance of the tilling of a changing landscape?

"Our collaborative, creative process enabled a movement to deconstruct the strictures of academic texts, research reports and accounts that could never fully satisfy the sensory experience of a project set in the enlivening decay of a garden." 
This rendering aims to strike at the hegemony of how unique people gather, bear witness to one another and share spaces of meaning-making and lived experience. Not presuming to know, be or do for others in these precious and precarious ethical moments of research, we purposefully apprehended the roles and responsibilities through which diverse subjectivities enter into a relational presence/absence in context. Rather, this paper draws out from photographic images highlighting the movement and senses - sights, sounds, smells, and bonds within the images. Here we share occurrences that provide a snapshot into what actually happened in our social gardening practices, which were also shaped by privileged notes from the field. These visual images come with their own sublime trickiness of being "taken" in the act. Throughout the text we present our poetic observations intermingled with visual images to evoke some of the curiosity and wonder in this studied garden-scape of discovery. Our discovery, as an unearthing, evolves with a snapshot of: i) the poetic structure we brought to our project; ii) our intentional writing with the same rigor and vigor as expressed by the gardeners - a tribute to the stories of movement and expression; iii) recognition of a more responsive, organic process in the research project and reporting; iv) a noticing of the abilities of diverse beings, together in the garden, with wonder, awe and the element of surprise; and finally v) a summary of our photographic and poetic walk through the wildness of this garden.

\section{A Poetic Structure in a Wild Garden}

Richardson's (1997) framework for narrative poetry is useful in terms of describing poetic representation as using pleated texts to conceptualize the multiplicities of presences and absences. Richardson encourages the researcher's use of poetry to capture and weave the rhythms (e.g., repetitions), tonality, patterns and texture (e.g., the layeredness of texts) that comprise speech, where poetry gives voice to participants' words and voice. Leggo (2008) contends that "poetry invites us to experiment with language, to create, to know, to engage creatively and imaginatively with experience" (p. 165) as a means of shaping discursive textual moments as art. It is in the quiet moments that poetry "brings our attention to dwell," at times in difficulty as much as in joy, "evoking affect and gestures that attend to subjugated voices" (Leavy, 2015, p. 77). Hirschfield (1997) suggests that different possible worlds and realities emerge when perceiving disparate elements and images. In our project, photos documented and served as a reminder of the activities in our participatory research project. Our poetic reflection on those photos serves simply to hold the moment and enable dwelling with those voices that can emerge from the colour and action caught in time and space.

This is not a photovoice (Wang \& Burris, 1997) or otherwise structured or theorized rendering, but rather a creative and poetic illustration of the motion and senses of a time in the garden as part of a larger project. In the social sciences, poetry offers discussion, attending to the craft of poetry to impart important narratives, and offers a means of reaching out to an audience (Faulkner, 2009). We heed Faulkner's advice by attending to images and observations that tell the story as a tribute to our time in the garden. The visual exploration of still photos depicting the motion of community 
and gardening further issues a glimpse into Massumi's (2011) occurrent art as experience of the present and anticipation that there is more to be revealed, more to understand, and more yet to occur.

The language of poetry emerged as we made sense of our notes and images. As we intermingled sentience with garden metaphors we refrained from the highly structured, obvious or prosaic (Prendergast, 2009), choosing rather, to sculpt landscapes of poetry with hints of the wildness of our garden. We also attended to how threads of poetry arose from the complexity of human experience that moved with a situatedness in each minute event (Galvin \& Prendergast, 2016). Our assumptions were not always self-evident, even as we toiled with these reflections. Rather, we aimed to hold the rigor with the vigor of our co-participation through curiosity and patience (Metzger, 1992). Simultaneously, we attended to the dominant discourses and influences that emerged in the person-earth-person (subject-object-subject) relations of cohabiting with this habitat. The tilling and toiling of our poetic renderings served to make sense of the images and observations in order to create a comprehensible account that reflected the purity of the moments and the becoming-ness of being with/in the garden.

\section{Writing with the Rigor and Vigor of the Gardeners}

Noticing tensile moments of humanness

amidst resisting absolutes

of documenting research in academ-ese.

Simultaneously,

relentlessly

practicing being together

in collective spaces

replete with simple offerings

of tending our garden.

The people tending and toiling in the inclusive campus-community garden were from many different groups and life experiences, brought together for just a few moments every week - throughout the growing season (May to September), in a Friday morning horticultural therapy program. Manning and Massumi (2014) write about being in the act "as a passage in the ecology of experience" (p. 18), as a sort of unfolding in the "gateway of moments" (p. 13), shaking us at the core of our identities, standards, and labels into an active poiesis. A sort of metamorphosis of dissonance (Braidotti, 2011, p. 28) shifted our habitual roles and responsibilities, and the world around our space felt frozen in time away from these moments in the garden. This shift in roles was the case for the collection of gardeners we gathered (for example those shown in Figure 1 ), and also in our reflection on the images and reflective poetry and writing. In this work we were deviating from norms and redefining subjectivities as each new occurrence grew new memories. We were called to ask, "Whose memories are these 
and how are these represented and disseminated?" Questioning tended to be weeded out in the poetic iterations we performed.

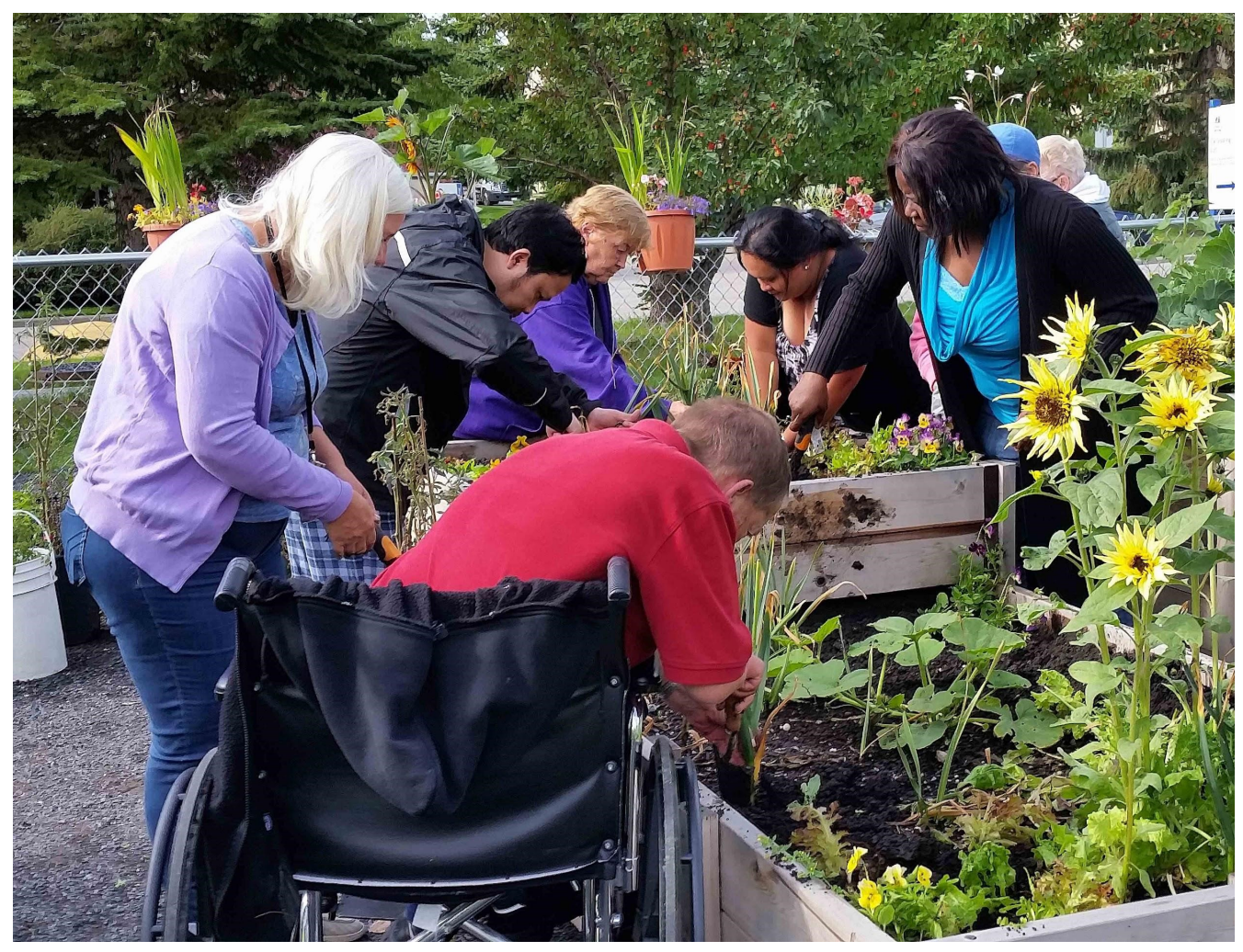

Figure 1: Tending in the garden

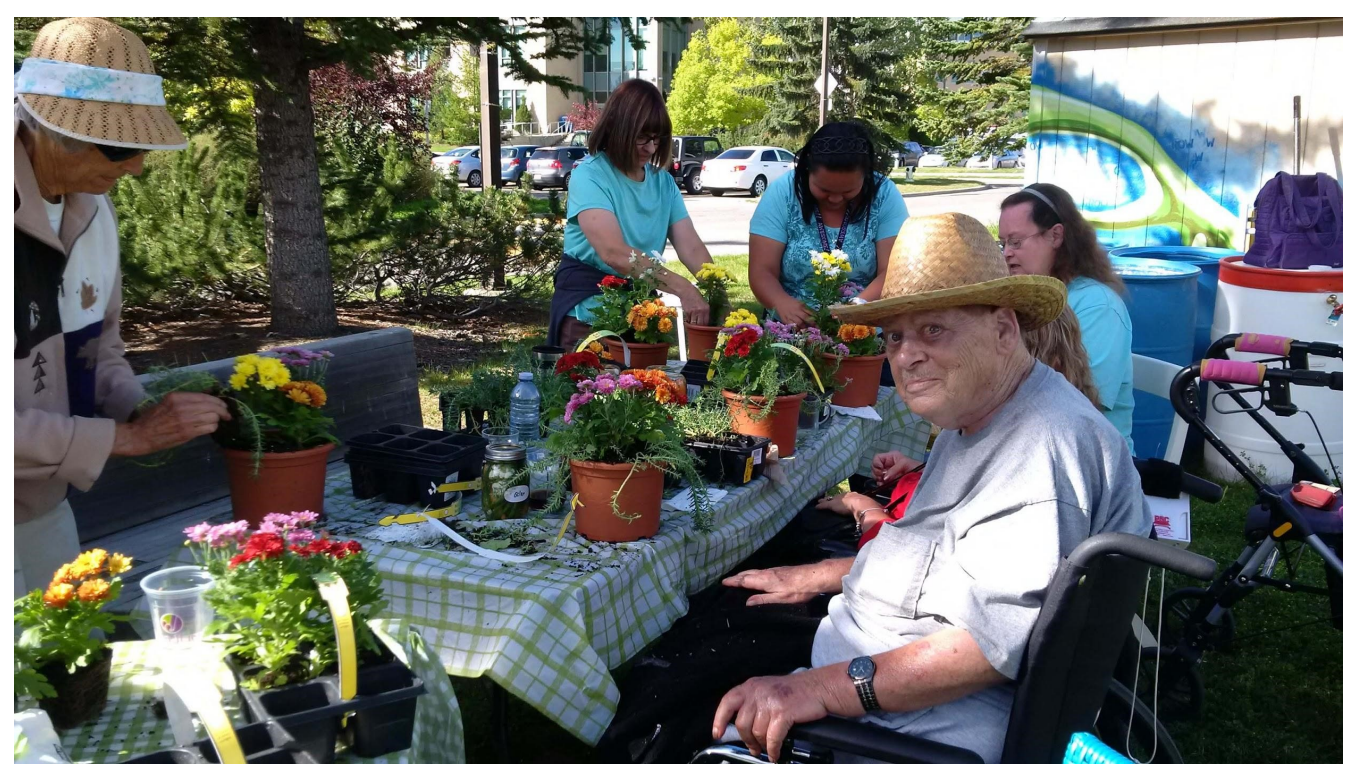

Figure 2: Activities at the garden picnic table 
Yearning for touch

in a world of safe distance.

Attending to gestures

As a ritual of sacredness

And emergent soulfulness

At the garden picnic.

Activity and attention feature in the garden images (such as Figure 2), whether capturing collective or solitary moments, playfulness or deep concentration. As in our poetic renderings, "ing" endings, symbolic of the flow of becoming, are always already a singularity for Agamben (1993) and rhizomatic complexity for Deleuze (1987, p. 263). Deterritorializing possibilities of hospitality, inclusion, and a rootless homing, infused with nomadic nuances were experienced through our acts of bearing witness to one another in moments of everydayness (Deleuze, 1987, p. 452). As such, the roaminghoming nuances serve to transform the ordinary into the extraordinary, convert background into foreground, and reshape mere existence into exhilaration. In accord with the hope and promise that lies dormant within fertile soil silently waiting to be awakened, lies the hope of being(s) coming-into-being: a longing for belonging in an all too transient world.

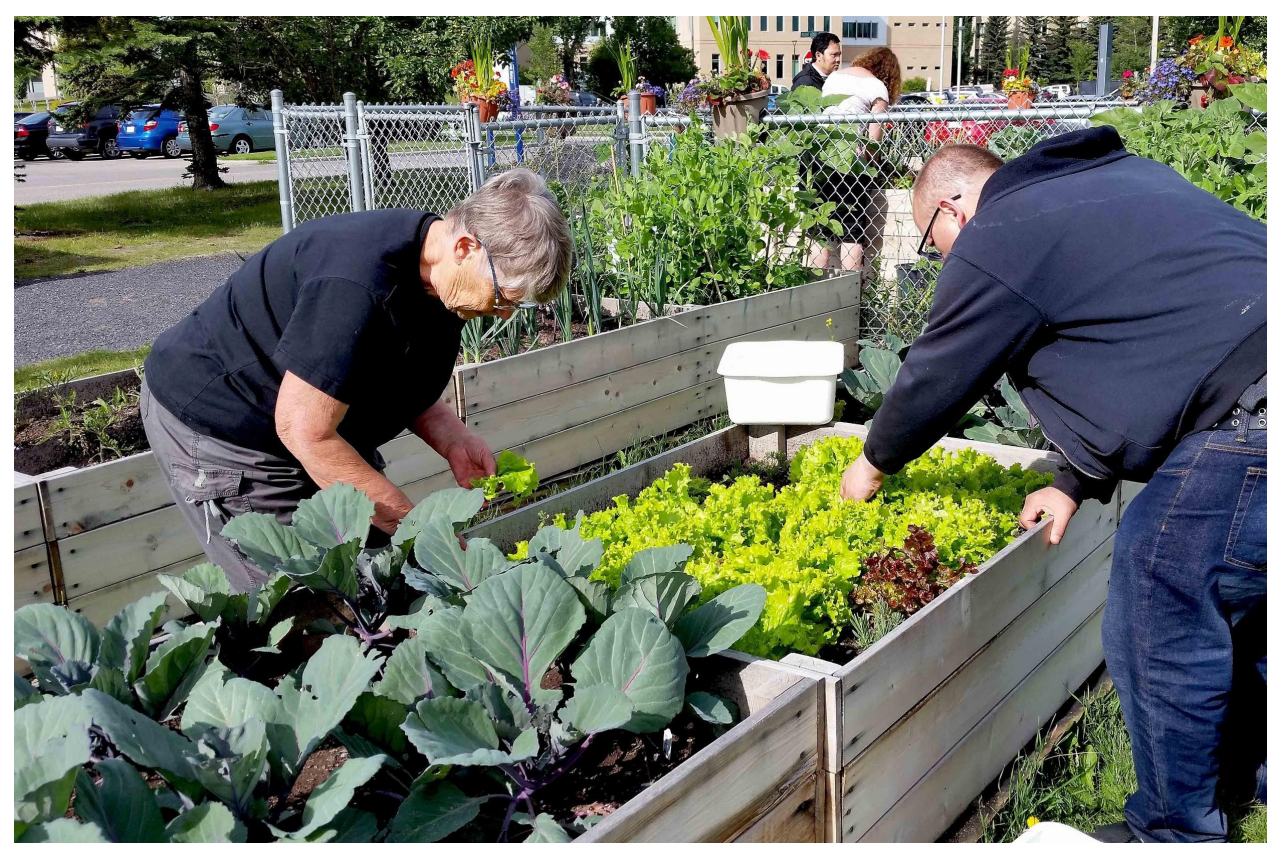

Figure 3: Reaching across raised beds 


\section{Eyes entranced}

beseeching contact

across raised beds

and leafy greens.

Hands holding touch

Feeling use-fulness

Reaching as/with a prolonging

promised vivacity.

Gardeners in the project drifted in and out as they needed or were able. Professional caregivers accompanied some participants, connecting to those in their care in new ways, and meeting with others they may not ordinarily have met in their day-to-day lives. Regardless of where participants drifted into the garden space from, everyone was digging into the same beds to co-create and harvest (see Figures 3 and 4). A gaiaosphy, for those drifting and wandering through/within the lifeblood of living together among the leaves and berries, is a vital spiritual ecology (Zoetman, 1989), forever shaking the foundations of arbitrary binary and dichotomous labels of age, ability and reason-ability.

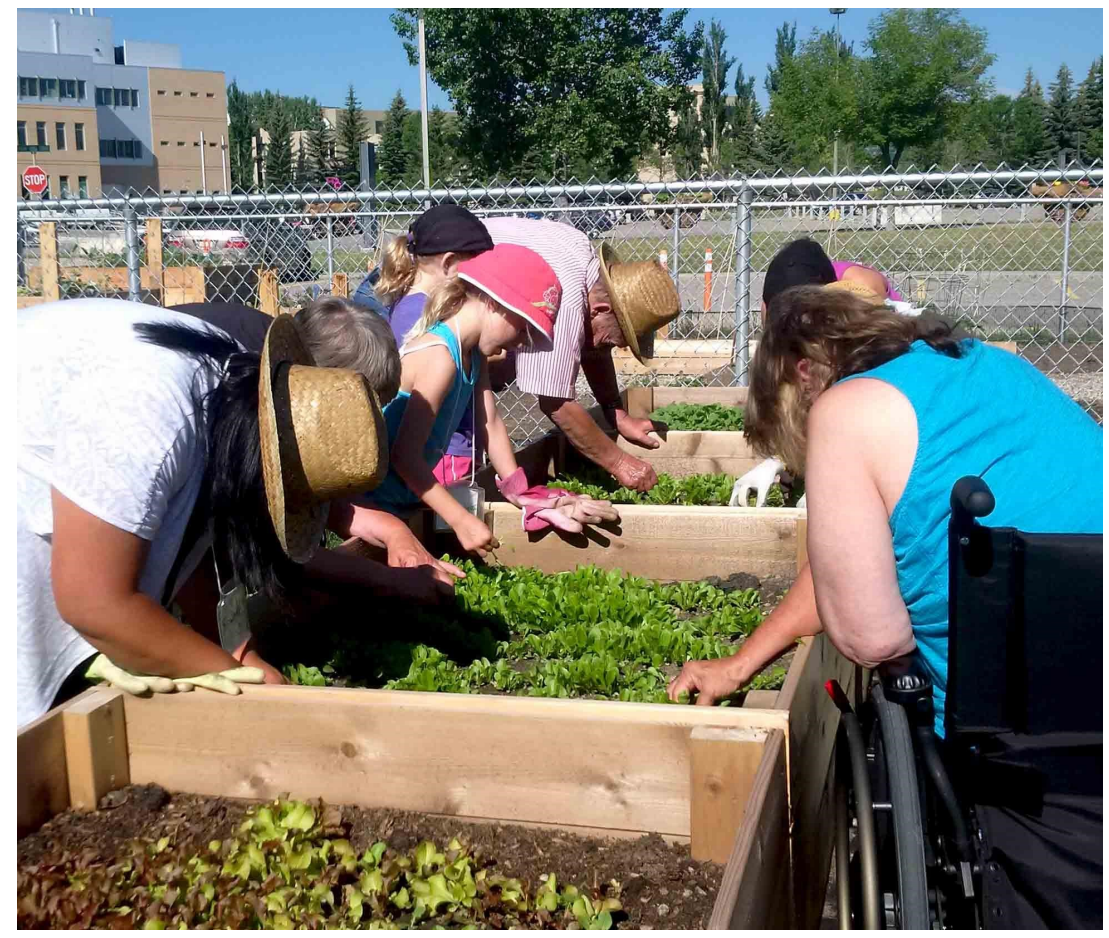

Figure 4: More arms reaching for synchrony 
Arms reaching in

Holding the warmth

As an embrace of earth and its people.

Nurturing synchronies at play

Attending the garden space.

In the comings and goings, drifting in and out of the garden space, the work was not simply busy work to perform tasks. Each gathering blossomed into a new and renewed mandala of colour and splendor. Here a conversation flowed, there a physical task ebbed, where both nurtured and revealed new stages of growth. Each act energized by the power and potential that was awakened from its dormancy by the pull of the collective and the response of the individual. The release was ushered forward not because this was the task that had been set forth for this day or that, but because of an all-encompassing trust, acceptance, and loving camaraderie. The body without organs acts as a mapping of possible movements, enacting one's subjectivity as if with/ through an intermingling of constructed boundaries - a play of subjectivities amidst the corporeality that crystallizes the flesh we have in common (Grosz, 1994, pp. 95-96). A sub-versive mission honours the fragility of being human and apprehends the mystery (without capture) when language is not enough (Prendergast, 2009), propelling and compelling mind and body into a oneness so lacking within a culture sometimes too narrowly focused on analysis, rationality, and logic.

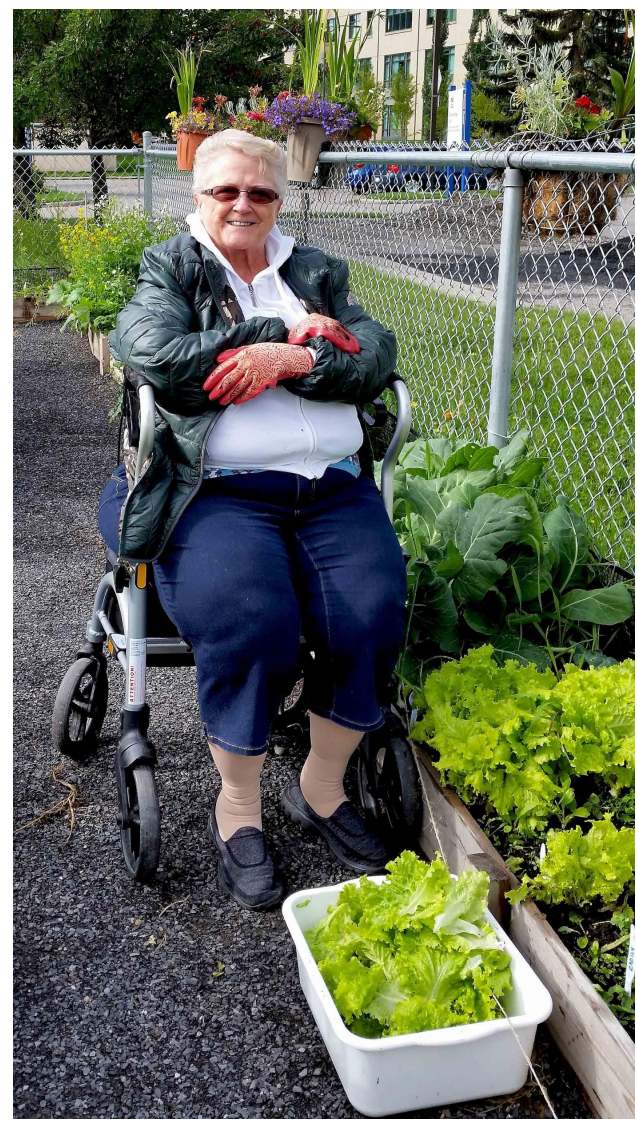

Figure 5: A gardener listens, loves and smiles again 
Speech in public spaces

where listening is robust.

Voices rippling

into the echoes of trees

Heralding the importance of

Sharing wholeness

with tenderhearted listeners.

Smiles aching to be witnessed

Here holding

the tensile moments

of comings and goings

Interlopers in these sentient bodies

in this garden of experimental wizardry.

Bending bodies

Craving to reach for ....more. Holding onto the weightedness

of feeling part of

something

other than managing risks and liabilities.

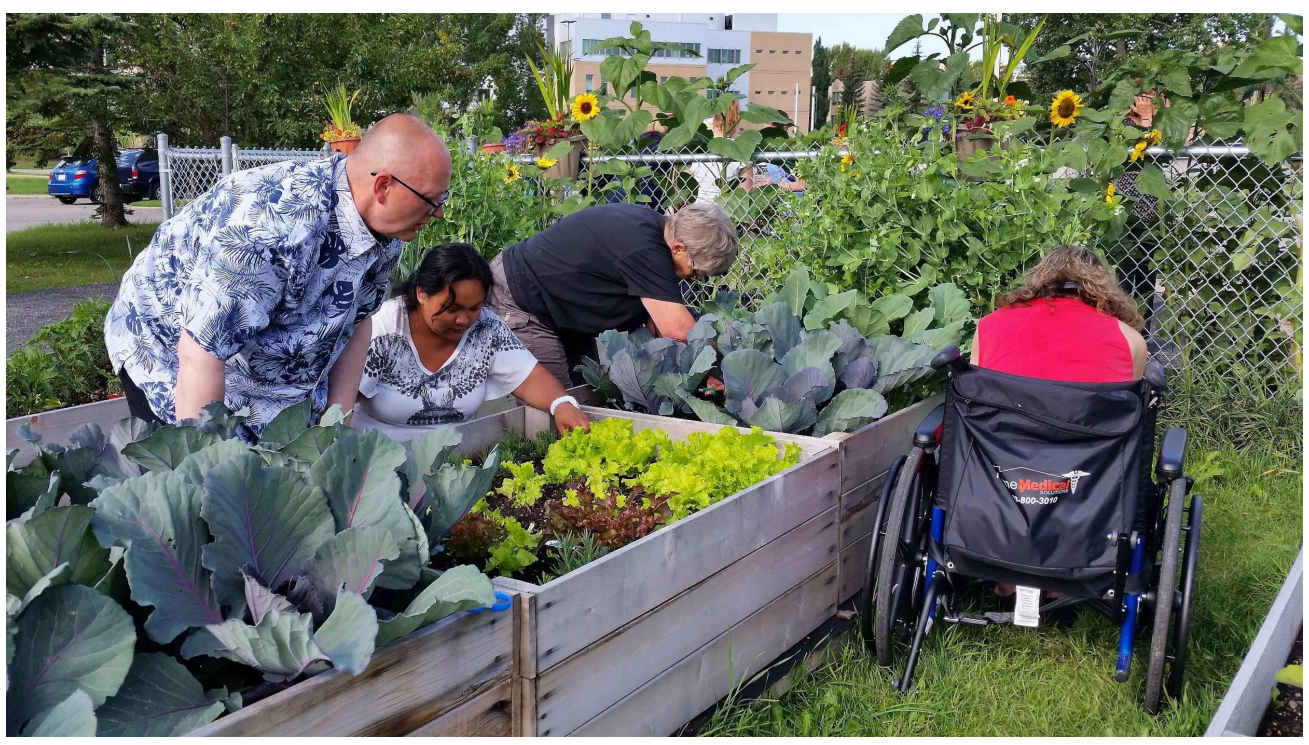

Figure 6: Bending and extending past the institutional boundaries

Moments infuse the images of what was shared as we connected/dis-connected in the ebb and flow of the social texture of the garden-scape, imagining at a glance (Weber, 2008, p. 43) the opportunities and possibilities, as if we had a choice. Impossible representations captured an instant, beckoning us to pay attention as we gaze upon the nuances, refusing to appropriate the voice or language of another (Leavy, 2015), and honouring the gestures that embody the rhythms of sowing and harvesting our time together. The images depicted in our photographs (such as Figures 
5 and 6) provided a deeper invitation, as though one had been right there, anchoring us all to the place and time, and suggesting the banal in the absences of what cannot be seen (Barthes, 1977, p. 39). Like Grosz (2009), we are painting sensations with words, bringing intensity to the imagined forces and energies, affirming Deleuzian "plans of composition" as the collective condition of art-making is distinguishing "blocks of materiality becoming-sensation" (p. 84). The anticipation of the zones of indeterminacy between subject and object in the images (such as the activity captured in Figure 7) attend to the sentience of bodies in motion, in the art/act of gardening.

Listening to the magic

of storytelling

followed by the sound

of little footsteps

knocking on the shed floor, harkening a freedom, an awakening of spirit and kinship in moments of blissful letting go...

\section{Tossing Salad and the Poetics of Institutional Boundaries in the Garden-scape}

The growth of language concerning leisure, abilities and access serves as a constant reminder that we are always already negotiating categories (Connolly, 2011, p. 90 ). These negotiations require both joys and sorrows, and play-filled qualities. As we conceded this complex social situatedness, we created space for leisure to breathe the memories of narrative lives into inquiry (Raisborough \& Bhatti, 2007). We aimed to resist the structures that determine how we fill our space and time with the reproduction of stereotyped, organized, labeled, categorized roles and relations (Parry, Glover \& Shinew, 2005). We accounted for being lured back to institutional life even in this open space amidst the re-surfacing nature and permeability of boundaries of the place we shared in common through sensorial re-conscribed ecologies (Ryan, 2013). Even in the wildest of gardens (or most participatory and exploratory of research projects), there are always already structures and boundaries that isolate us from nature and our naturalness.

Rendering the ubiquitous boundaries that construct a research project,

with scripted

Human

Research

Ethics

Board

Approvals. 
Our use of poetry as a method within participatory research was a movement more than a methodological structure. The approach expanded and contracted in the cracking façade of tensile, rhetorical masks (Kamberelis \& Dimitriadis, 2005, p. 891). The movement demanded noticing, in particular noticing and drawing out dominant discourses that shaped identities, roles, responsibilities and the actualities of our everyday garden context. Researching people in public spaces, however, also necessarily requires a framing through the institutionalizing roles and forms. These are forms and frames that impart an otherness and objectification that are always present, even in the structuring of this text. Our analysis through a poetic and visual form attempted to engage a simultaneous process of awakening alongside the institutional realities. In this endeavour we took the opportunity to observe other experiences and happenings beyond the confines and limits necessarily constructed by research. Awakening in this way, is a process Hanh (2013) also explains in poetry:

Noticing and being noticed

Colors, scents, textures and movements

Organic flow between Gaia

and the spirit of nonviolent,

collective awakenings. (p. 26)

As we do not have the immediacy of voices of multiple others, the image is held as a sacred pact that reminds us that our notes in the field are shaped by the precariousness of being "caught" in an act, even with consent. The images are weaving the invisible conditions, circumstances and intentions of actual practices and people when reproducing a social interaction in a particular setting in any iteration (Kemmis \& McTaggart, 2005, p. 565). Images provided spaces for inviting uniqueness and difference and welcoming the human foreignness that had been cultivated and held hostage in the structure and form of all things (Dufourmantelle, cited in Derrida, 2000).

Where poetic openings shift Theoretical and philosophical dysmorphic forming Toward a playful praxis of inciting And enticing sensory whimsy Savour the event In unfolding flavors

Even here in the explications! Rupturing grammatical accuracies

Creating dis-ease among

Writers, readers

and those bearing witness

To the power of the text

Over its experimental angst

Tossed salad of habitus At play with our shifting foundations. 


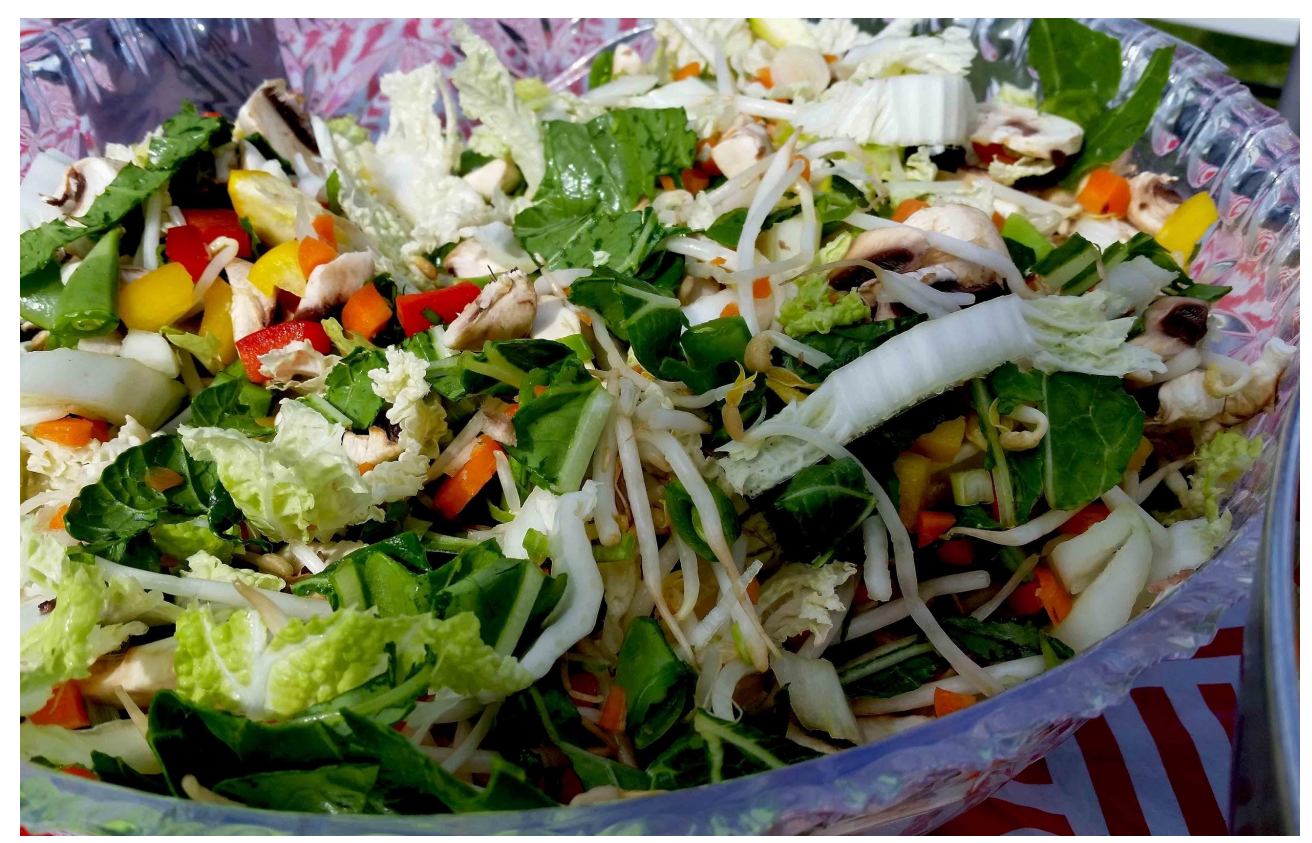

Figure 8: Tossed salad with tangy dressing on the garden picnic menu

Conventions of research were adhered to in the community garden research project. For instance, human subject research ethics certification was obtained, and records were kept systematically in an effort to maintain the integrity of data. Other conventions were experimented with, true to participatory research processes. Just as we harvested, prepared and tossed interesting salads as a ritual at the end of each Friday garden session (see Figure 8), our poetic renderings and photographic reflections formed an analytic ritual that enlivened the senses for the research team of listed authors. At play with our nomadic sense-abilities in our garden oasis, we turned to Braidotti's (2011) description of discourse to shake and toss around the elements of discourse within the images and observations from the garden project.

Braidotti amplifies attention on the structural aporia emergent from conventional theory and philosophy unaccustomed to hybrid, decentralized dialectics that mobilize and evoke subjective localities (2011, p. 12). In so doing, discourse, in the poststructuralist sense is a process of production of ideas, knowledge, texts and sciences, and practiced in the ritualized cultural, political repetitions, moving "across established categories and levels of experience: blurring boundaries without burning bridges" (Braidotti, 2011, p. 36). Leggo (2008), extends such discursive textual moments to art, as a vehicle to experiencing sensory perception and provocation with important potential to influence how we share the stories we live, in our case in the unique lives coming together in the garden. 


\section{Noticing Physical and Ecological Ability with Wonder, Awe and Surprise}

Our participatory research project, purposefully sought to engage people with disabilities, caregivers, researchers, students, and various community members in a shared role of "gardener." In focusing on this shared experience, the embodied realities of pain, disability, limited mobility, and environmental obstacles - such as the elements and accessibility problems in the physical space or as dealing with transportation systems - were held with attentive openness, rather than formed through a labelled body politic. Wolbring (2013) challenges the discourses of disempowering and externalizing corporeality as disability body politics that dictate accessibility by normative expectations. Such discourses further reinforce ableism in frameworks of "eco-ability," anthropocentric approaches to ecohealth (Wolbring, 2013, p. 14). We attempt to shake the superfluousness of the prefix "dis" - where we are obviously and obliviously able. Gardening without the "dis" (as an invitation to imagine otherwise) preserved the elements of personhood (as more than bodies and ableism) that expressed a just, shared equality in the collective work.

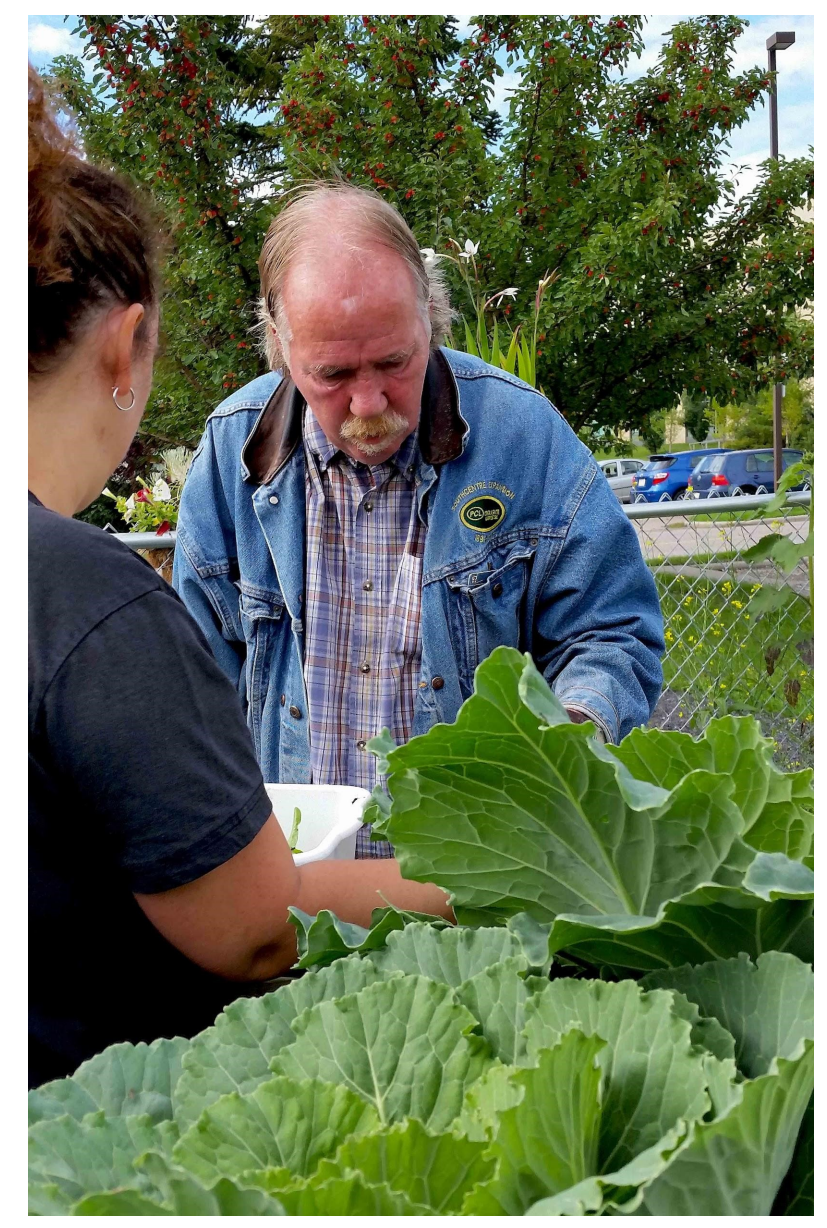

Figure 9: Tending the garden after coffee break 


\section{Institutionalizing insidious sores invade the organic fertility with the dis-stancing branding of diagnoses and protectionism. \\ What I know about Z Is his love for his morning coffee and smokes before we begin the garden inspection of what needs tending.}

All research project data was gathered without a focus on recording aspects of disease, disorder and diagnosis. Instead the focus was on participants' experiences in the garden, and getting to know their interests, strengths and preferences, including professional caregivers and all involved (see Figure 9). Participants had to be able to consent to participate and be physically able to be present in the garden, but otherwise participants simply attended the program and tended to the garden in ways that fit their abilities and interests, doing so at their own pace. To the point of abilities, Wendell (1996) contends that the designation of "disabled" serves the purpose of justifying needs (e.g., the label is required in order to obtain medical and social support services one needs for survival) and simultaneously creates subsystems of meaning (labels that identify through othering) that reinforce false perceptions of uniquely lived experiences.

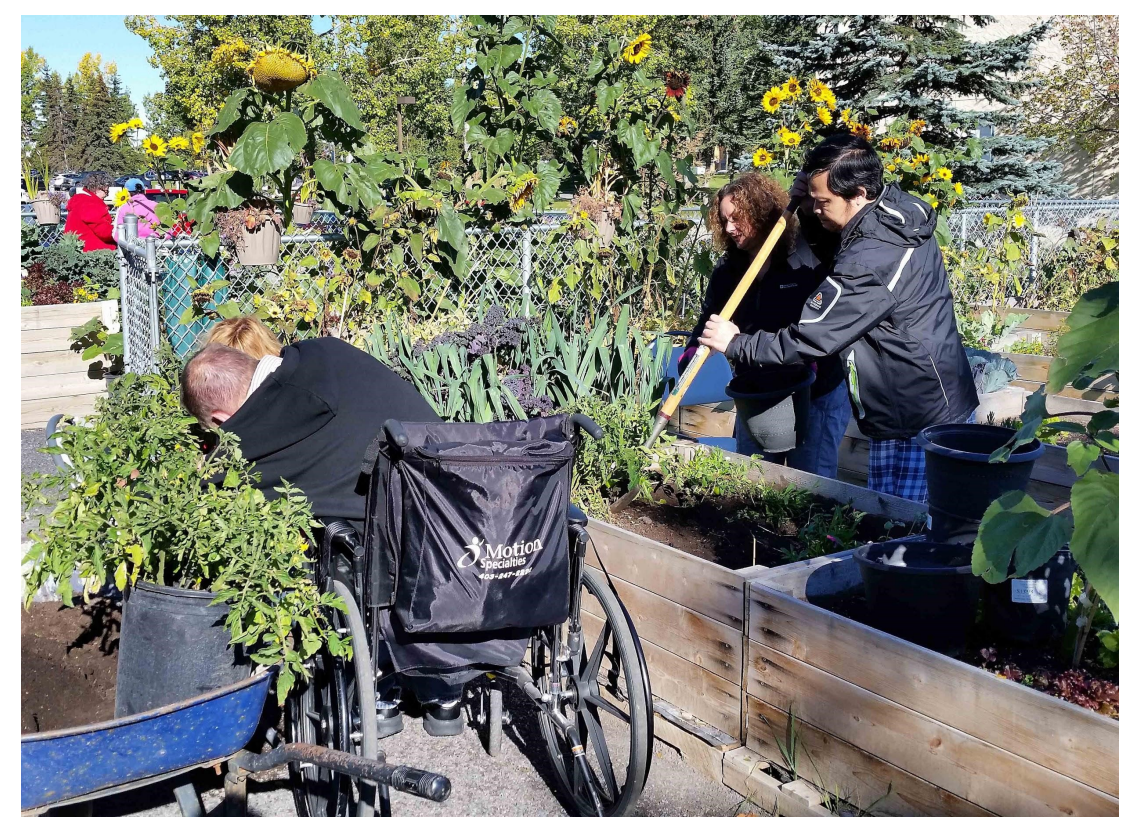

Figure 10: Active and alive in the garden 
Wanting to find social anima

Without stigma

when we become alien

Beyond this ivy perimeter

That grows resistant

to the activities

For the sake of

occupying our seemingly

idle hands.

It's not okay to be co-opted!

Notice that tomato needs watering!

This garden needs care when we are away!

Speaking in public spaces

seeking to be recognized

as a presence that heralds the coming

of fruitful harvests.

The community garden site established a place for mythmaking of the nomadic subject, and the qualities of interconnectedness with "critical consciousness that resists settling into socially coded modes of thought and behavior" (Braidotti, 2011, p. 26). The nomad in this sense, is already subjugated "in transit and yet sufficiently anchored to a historic position to accept responsibility . . . confining all 'others' to the position of periphery" (Braidotti, 2011, p. 36). Holding sentient beings in intersecting moments at the very center of public spheres of influence is a collective affluence, as depicted in Figure 10. In this place of being seen and heard in a narrative accounting of the precious/precarious moments we shared in common was a natality of sorts (Arendt, 1958). While gardeners sought the engagement and activity, the activities in our open and public space also relied on all the gardeners involved, and the tilling and toiling of a profound mutuality.

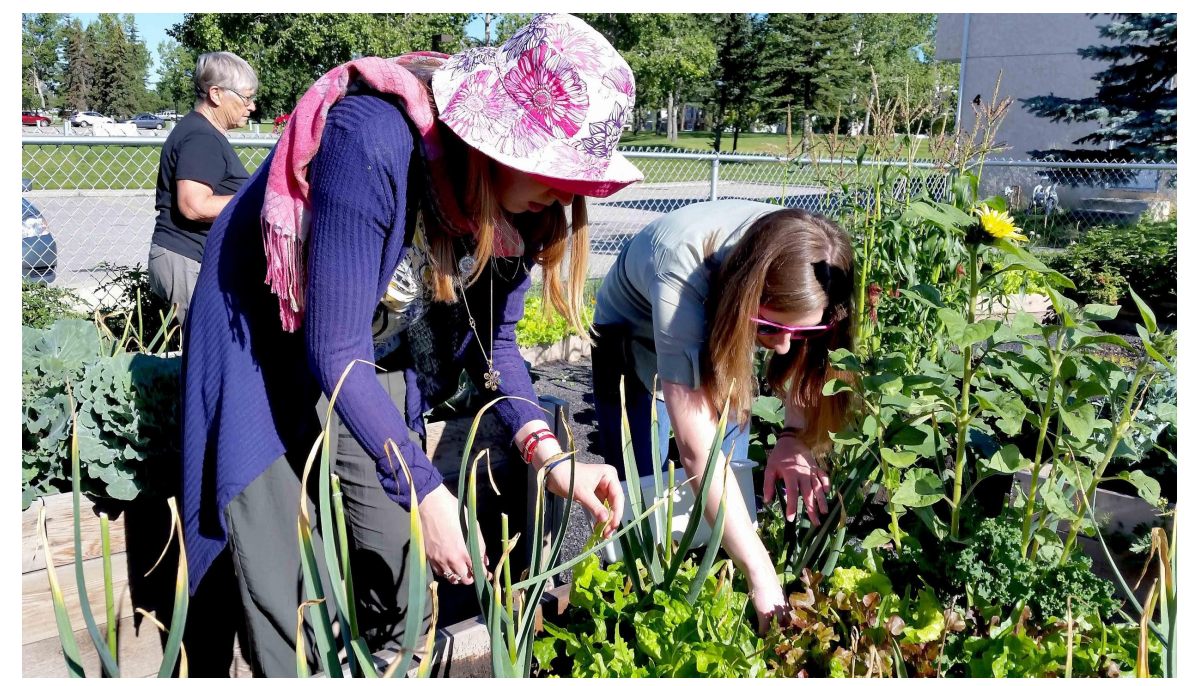

Figure 11: Mingling with each other and Mother Nature 
Sowing seeds

thinning seedlings

Tilling soil

Tossing salad

Objects and acts

mingling

with one another

With Her.

The idea of digging with another, feeling the weight and texture of the soil "creates an affinity or sense of belonging" (Pink, 2009, p. 76) to another. Our gardening work prompted the sharing of memories of childhood farms, remembering the difference between types of kohlrabi, recalling recipes, or the delicate scent of a stern grandmother's sweat pea patch, all as instances of reflexivity in our research project. Mingling in the garden space and activities (see Figure 11) enabled discussion and storytelling.

Welcoming nomads no longer passersby from far away Or nearby places

Seeping into the flow of things

Ruminating about the sun Catching light among the leaves.

Curious about the storied lives of this hodgepodge of ramblers.

Willing the invitation to step in, to taste the harvest.

Dwelling

In our collective en-tranc-ing, spellbinding reverie.

Honouring each moment began anew, with a certain "daily-ness," required in any garden. We quietly attended to the comings and goings of a medley of people of all abilities and ages, as in Figure 12, collectively occupied by various tasks at hand: the seeding, germinating, tending, harvesting, preserving, and the ultimate closing clean-up at the end of season. Somehow, however, all these rituals emerged as though for the first time, season after season. Noticing both ritual and subtle changes (see Figure 13) became as consequential as the watering and tilling. 


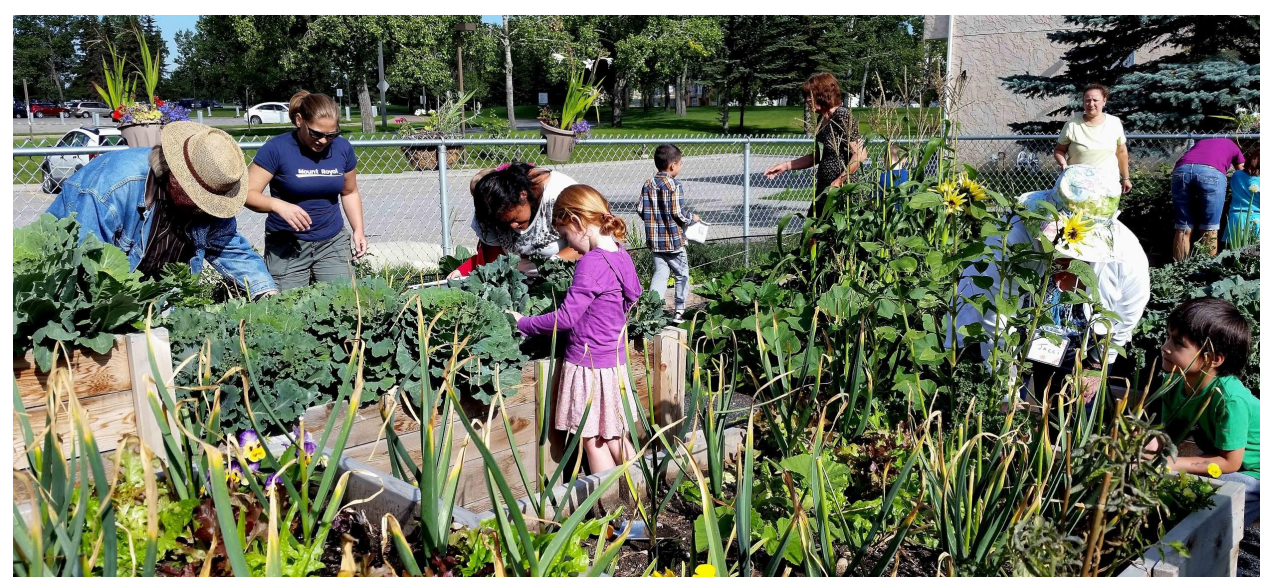

Figure 12: A medley of gardeners

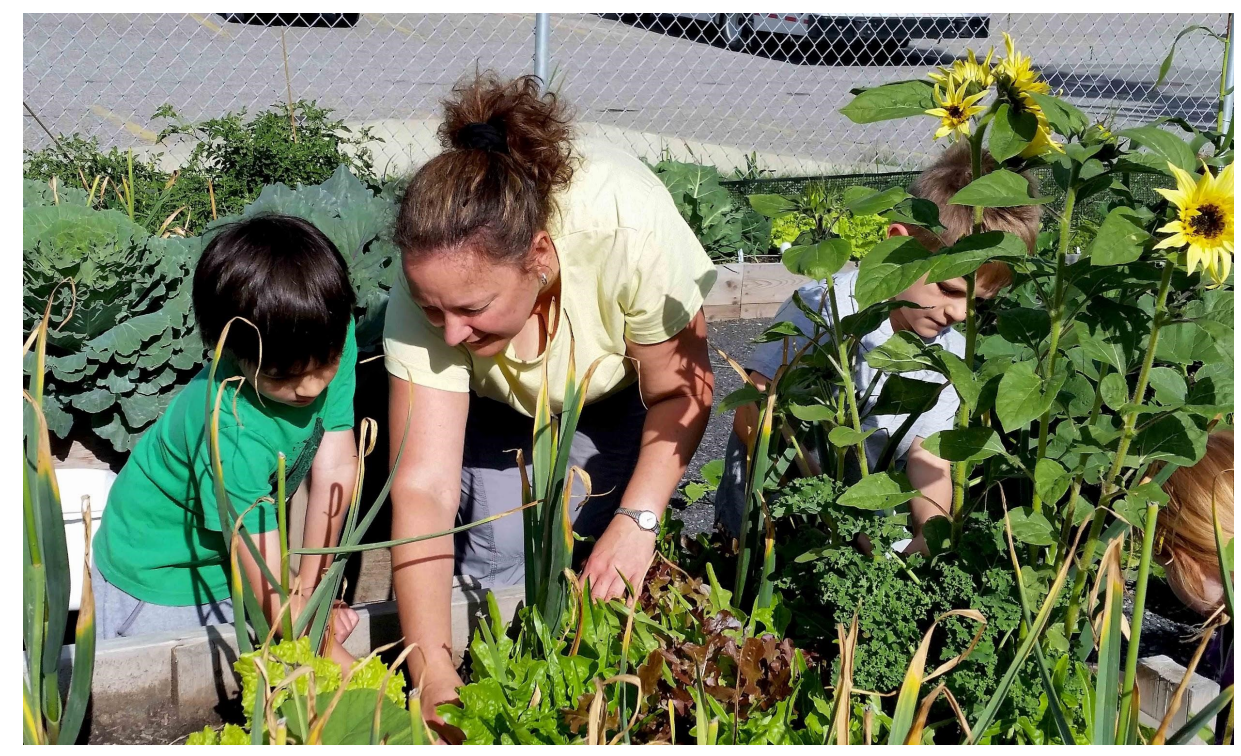

Figure 13: Are the kids coming today?

$J$ is missing today

Is she okay?

Are the kids coming today?

It's not the same without them.

Observations of the rituals and changes highlighted excitement and struggle in the lives of all participants. Unique moments in the garden caught different participants' attention. The interwoven landscapes and narratives could be threaded through a memory of "cauliflower that looks like brains." 


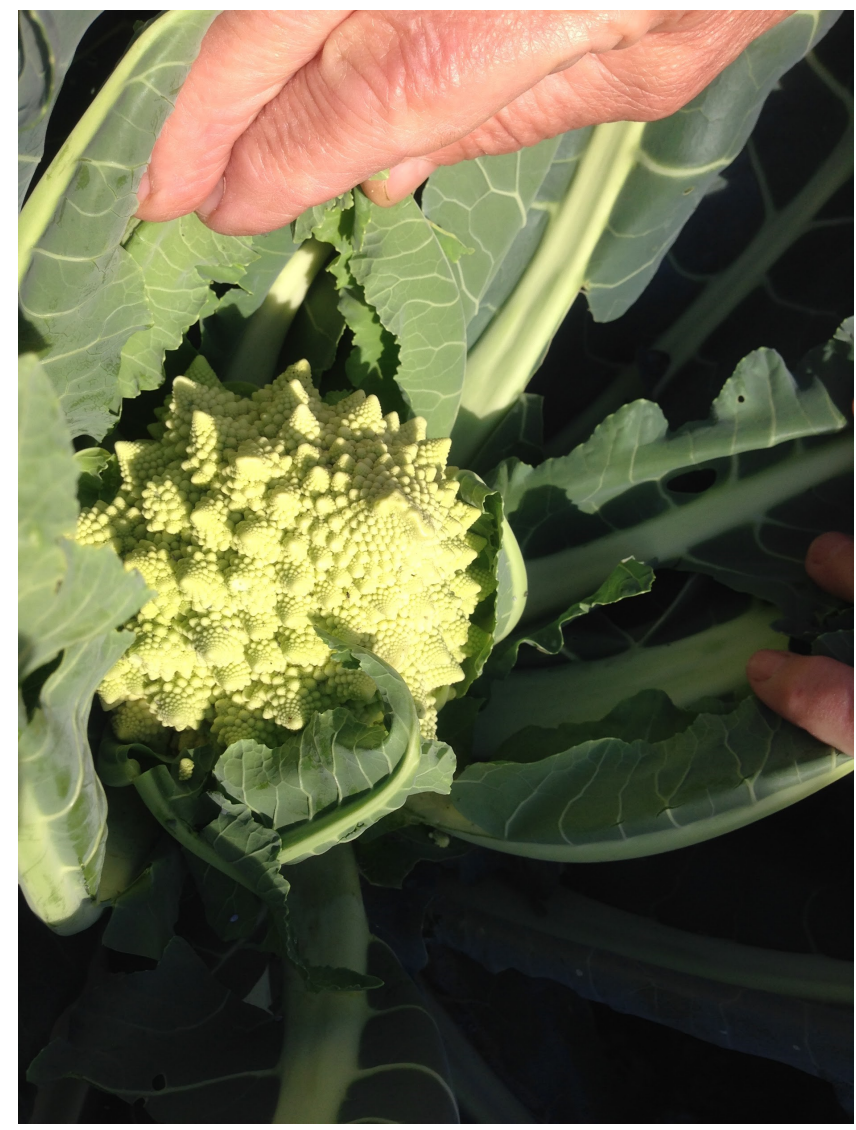

Figure 14: Cauliflower that looks like brains

Subtle and not so subtle changes or interesting discoveries in the garden (such as Figure 14) imparted a sense of wonder and compassion that extended to all participants, and awareness of our challenges, struggles, and joys. Caregivers and colleagues, all observed themselves and others anew.

$N$ is a totally different person here.

He has a smile for everyone and a warm hug $V$ is 'ready to go' for her mornings in the garden, usually we can't get her to do anything. It's good for me to get to know them outside the [residential care] Centre.

A dance between slow movements and organicity (Figures 15-20) shapes new bonds that have force and vitality (Bonta \& Protevi, 2004), shifting bodies with the capacity of attunement to "a whole rhizomatic labor of perception" in the ontology of difference and repetition (Bonta \& Protevi, 2004, p. 146). Complicit in the crystallization of reflexive moments lingering in the compost heap of memory (Bonta \& Protevi, 2004, p. 112), desiring machines are acting with/in mutual pleasure. The emerging joyful affect is more than a new cosmic cloak of leisurely collective acting between naturalization and socialization (Latour, 2004, p. 73). Perhaps, rather, the joy of collective work acts as an 
emergent sentient event. In this way, the senses are expanded as they are reflexively shared, navigating us in our commonalities and in relation with one another in the anthropocene - reconfiguring relations with a complex habitat inhabited by the alterity of the spectral dimensions of the post-human subject (Braidotti, 2013, p. 81).

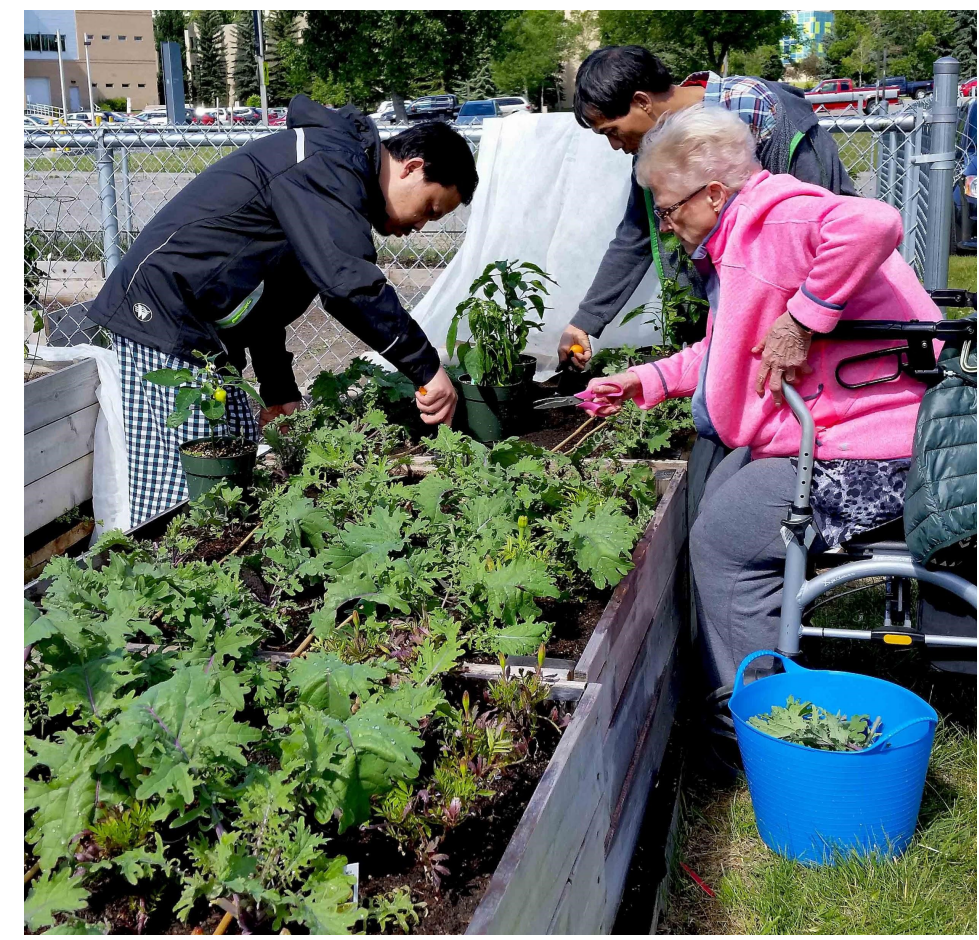

Figure 15: Idle no more

Longing to be needed

To serve another

And not be served

As "resident,"

Estranged,

Host of foreign-ness.

Hostage to the residue

Of discourses that make

Idleness

Habitual.

We follow Manning and Massumi (2014) as they write into "the boundary between experiencing and imagining in the yet untold ... [an] oscillation composed within the threshold of express-ability" (pp. 5-6). A gentle, but radical, movement into the possibilities of the space and time enabled a certain suspension of the patterns held outside of our shared ground. 


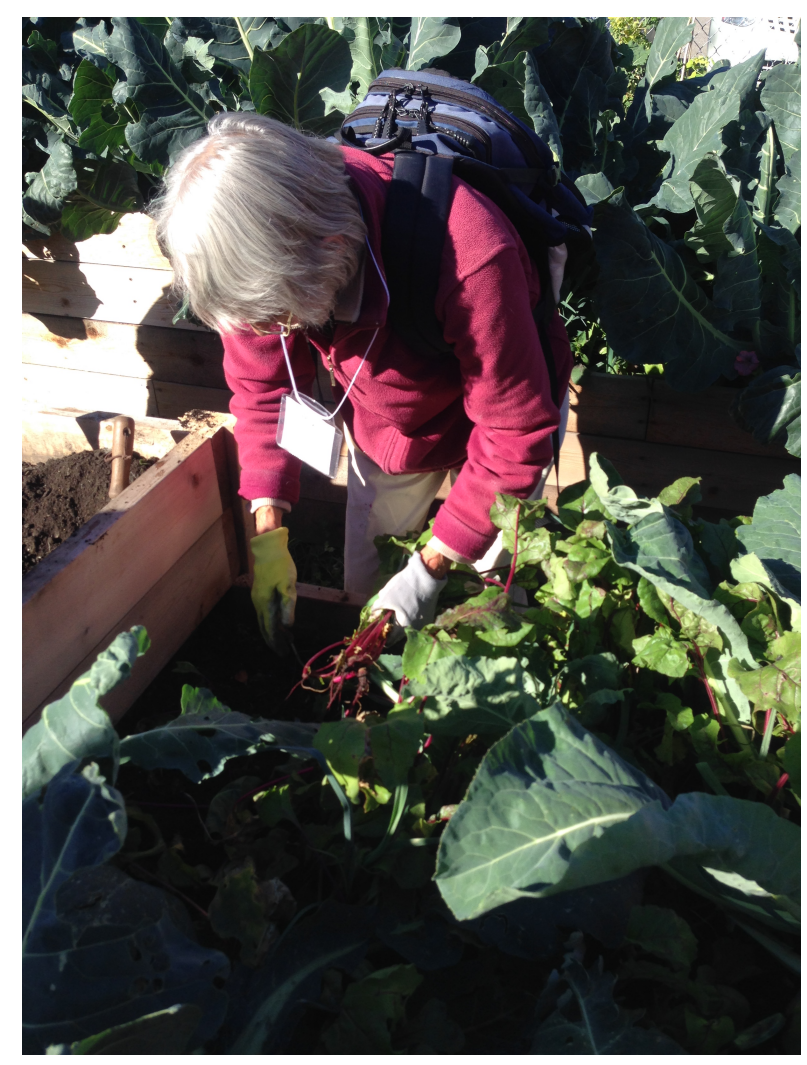

Figure16: Surrendering to this moment in the garden

Weaving the multiplicities of expectations and assumptions rendered in a research proposal and project holding people, space and time in captivity.

Moving in the making

Where making a move

Requires surrendering to the moment

Different from the 'must'-ness of instruction

And instrumentalism

Coaxing our awkward togetherness

Into a visceral bewilderment.

Surrendering personhood

To this new epoch of generative synchronicities. 


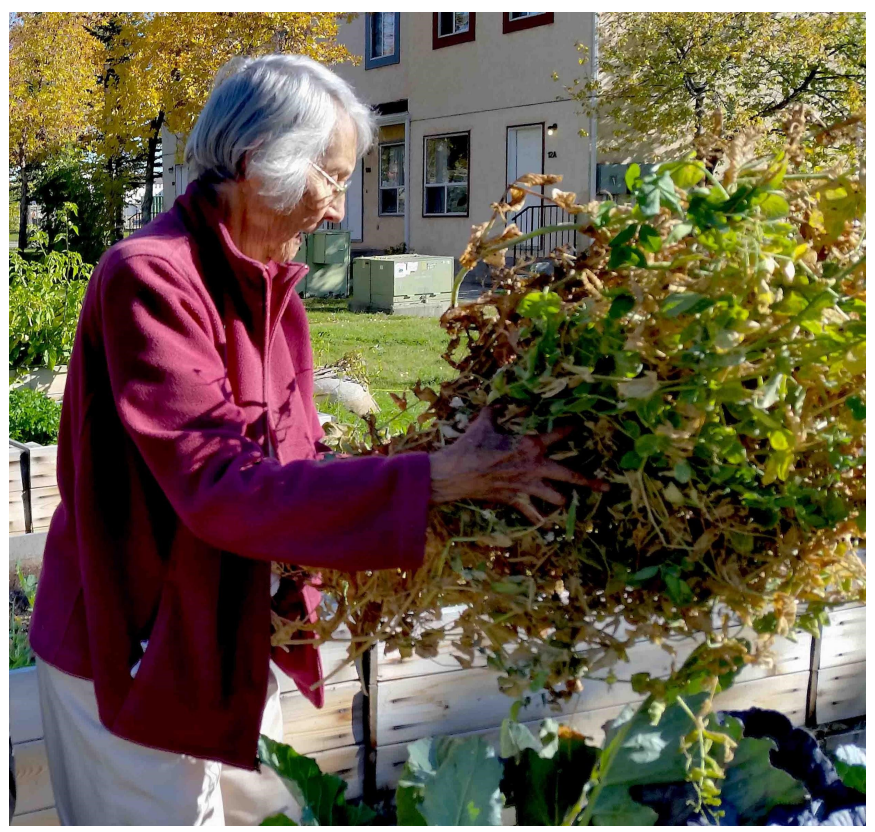

Figure 17: Surrendering with the garden's movement

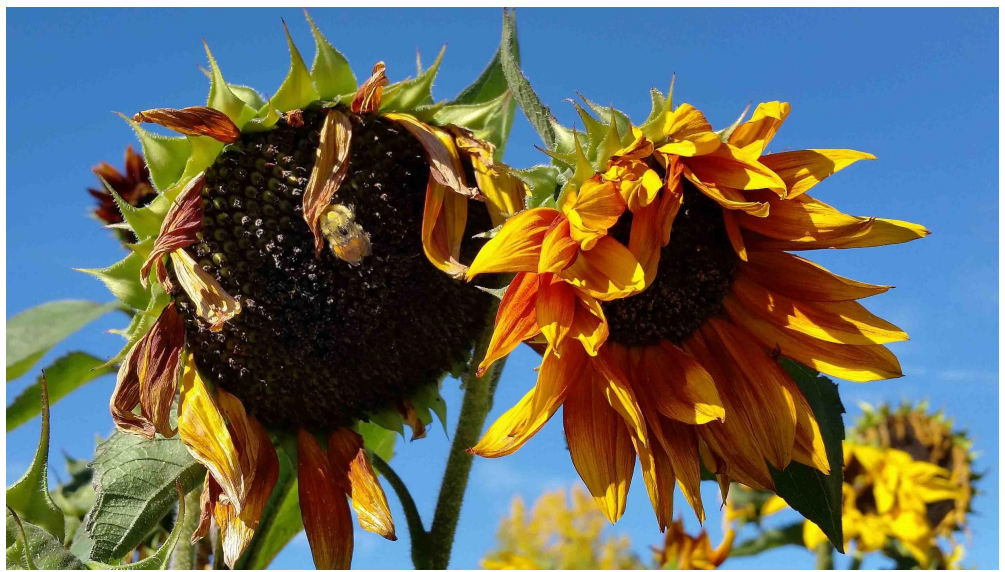

Figure 18: Noticing a surprise bee on the sunflower

A relational ethic of curiosity unfolding the wonder and awe amidst the tensile presence of bodies awaiting uninhibited 


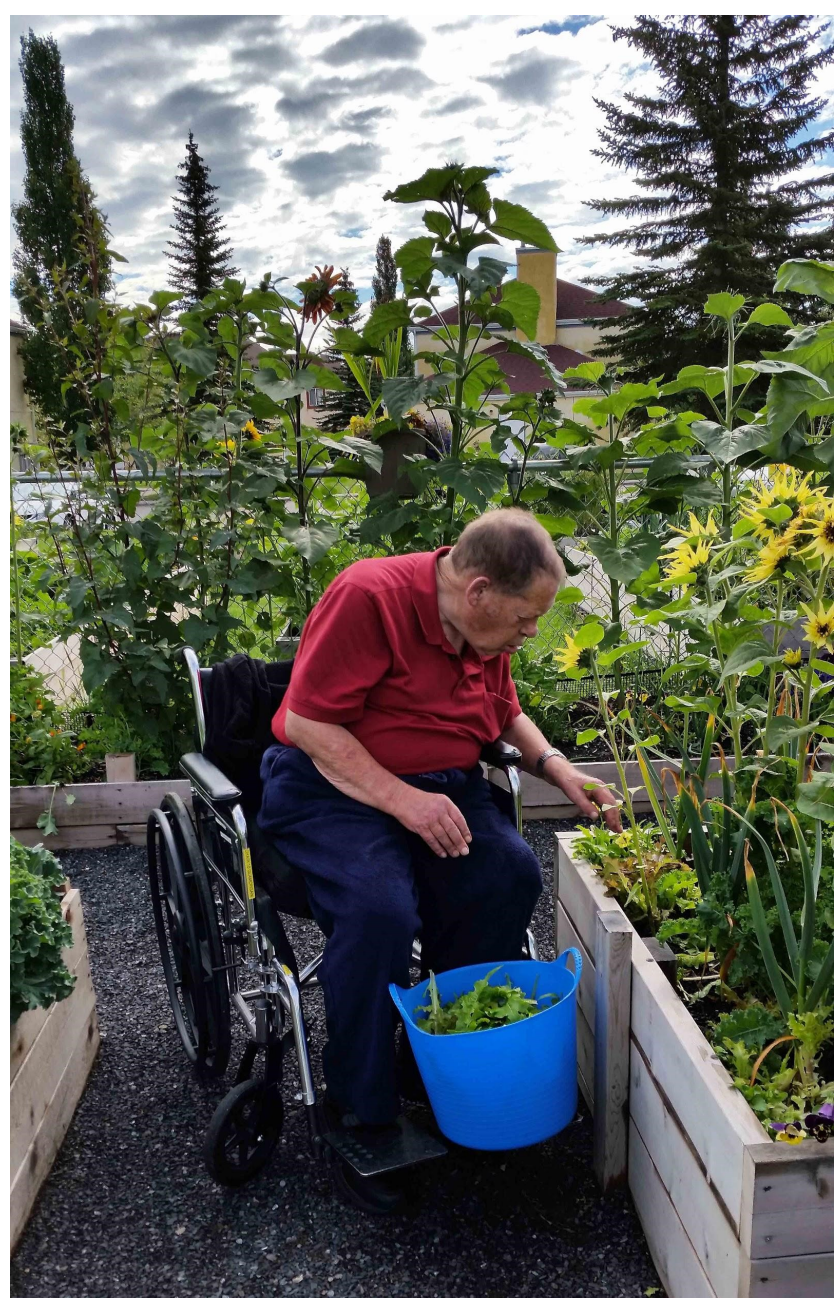

Figure 19: Gardening Rx with/out a diagnosis

unadulterated

SURPRISE!

Sparks ignite

When I hear your memories

Your laughter

crinkling your eyes

in ways I have not witnessed before.

Stripping away layers

of box world diagnosed identities

And yet not ever fully

nor completely free of that complicity. 


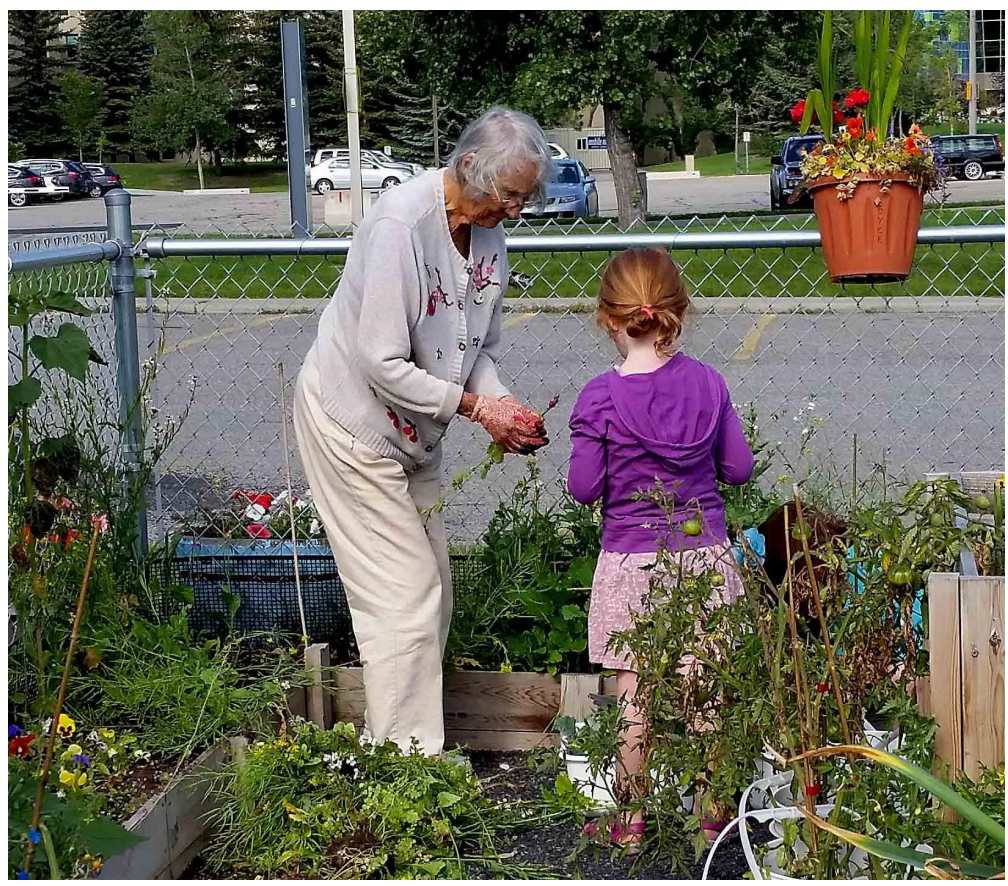

Figure 20: Sharing garden secrets

In the event

where a salad or preserve

manifests into sharing of recipes

passed through generations

Holding an invitation of

Home-ward-bound-ness

Drifting in on the wind

And sifted into the soil.

Now blossoming secrets

of the garden

to the privileged listeners

in this place of seasonal wonderment.

Rigid joints

Folding like petals

Gesturing

Sensuality

and nonsense.

Learning about the quirky Walking Egyptian onions, which also tell a story Of our time together in the garden. 


\section{Another Story of Our Time Together in the Garden: To be continued...}

This poetic and visual story of our inclusive campus-community garden project remains a necessarily insufficient and incomplete offering.

A stone dropped into a pond produces a ripple pattern. Two stones dropped into the same pond produce two ripple patterns. Where the ripples intersect, a new and complex pattern emerges reducible to neither one nor the other. This is the emergence of conceptual interference patterning. (Manning \& Massumi, 2014, p. vii)

We are nurturing in the texture of these reflexive and wilder moments. We hold the precariousness of Manning and Massumi's "rise of the free radical" as a "transversal force for unsettling the collective attunement" (p. 151), as an apparition, trickster or spectral manifestation of these events. Attuned to the poetic rendering inspired by static images filled with robust movement and texture, actual daily activities and stillness can also be tricked into greater wildness. We are poised to see the beautiful simplicity and complexities of our garden anew.

In closing this explication and poetic rendering, we leave open the uncovered, recovered, omnipresent, omniscient joy-sorrow that hovers beyond and within the stillness of the garden, beyond and within the sounds of resonant communal voices, beyond and within the questionings, the wonderings, the wanderings, and the meanderings. Though those voices on the page are now still(ed), now unnoticed, they yet remain. The voices are permanently etched into the garden-scape, the landscape, in the same way that "the earth is always faithfully there...[taking] in the diverse continuum of every life, and its memory [holding and preserving] it" (O'Donohue, 2010, p. 141). Those voices are alive, their faint yet distinctive echoes everlastingly projected onto and within the grand, mysterious concealment. In this way, ours is not the final word; indeed, it is not ours to be had, possessed, or valorized above all others. It is, rather, an interpretive offering with humility and gentle intention towards provocation, evocation, invocation and aliveness.

\section{Acknowledgements}

The authors wish to express thanks to co-researchers on the original participatory project, Judy Glesson, Janet Melrose, Angela Foster, and Elaine Schow, along with Research Assistants, Che Burnett and Jennifer Pelletier, as well as the many volunteers and gardeners whose joys and sorrows are alive in the garden and on this paper. We must also acknowledge the generous funding and support for the original project: Mount Royal University's Institute for Environmental Sustainability Research Grants; Internal Research Grants; Faculty of Health, Community and Education Innovation Funds; and TD Friends of the Environment Foundation. 


\section{REFERENCES}

Agamben, G. (1993). The coming community: Theory out of bounds (M. Hardt, Trans.). Minneapolis, MN: University of Minnesota Press.

Arendt, H. (1958). The human condition. Chicago, IL: University of Chicago Press.

Barthes, R. (1977). Image, music, text (S. Heath Trans.). New York: Hill \& Wang.

Bonta, M. \& Protevi, J. (2004). Deleuze and geophilosophy: A guide and glossary. Edinburgh, UK: Edinburgh University Press.

Braidotti, R. (2013). The posthuman. Cambridge, UK: Polity Press.

Braidotti, R. (2011). Nomadic theory. New York: Columbia University Press.

Cole, A. L. \& Knowles, J. G. (2008). Arts-informed research. In J. G. Knowles \& A. L. Cole (Eds.) Handbook of the arts in qualitative research (pp. 55-70). Thousand Oaks, CA: Sage.

Connolly, W.E. (2011). A world of becoming. Durham, NC: Duke University Press.

Deleuze, G., \& Guittari, F. (1987). A thousand plateaus: Capitalism and schizophrenia (B. Massumi, Trans.). Minneapolis, MN: University of Minnesota Press.

Dufourmantelle, A. \& Derrida, J. (2000). Of hospitality (R. Bowelby, Trans.). Stanford, CA: Stanford University Press.

Faulkner, S.L. (2009). Poetry as method: Reporting research through verse. New York: Routledge.

Galvin, K. T. \& Prendergast, M. (2016). Introduction. In K. T. Galvin \& M. Prendergast (Eds.) Poetic inquiry II - Seeing, caring, understanding: Using poetry as and for inquiry (pp. 3-20). Rotterdam, NL: Sense.

Grosz, E. (2009). Sensation: The earth, a people, art. In E. W. Holland, D. W. Smith \& C. J. Stivale (Eds.) Gilles Deleuze: Image and text (pp. 81-103). London, UK: Continuum. 
Grosz, E. (1994). Volatile bodies: Toward a corporeal feminism. Bloomington, IN: Indiana University Press.

Hanh, T. N. (2013). The bells of mindfulness. In L. Vaughan-Lee (Ed.) Spiritual ecology: The cry of the earth (pp. 25-28). Point Reyes Station, CA: Golden Sufi Center.

Hirschfield, J. (1997). Nine gates: Entering the mind of poetry. New York: HarperPerennial.

Jakubec, S. L., Gleeson, J., Flessati, S., Currie, G., Szabo-Hart, J., Mathison, B...Eirikson, A.D. (forthcoming). "It was like coming home again": Planting seeds of wellbeing through an inclusive campus community garden project for older adults. Journal of Therapeutic Horticulture.

Kamberelis, G. \& Dimitriadis (2005). Focus groups: Strategic articulations of pedagogy, politics, and inquiry. In N. K. Denzin \& Y. S. Lincoln (Eds.) The Sage Handbook of Qualitative Research (3rd ed.) (pp. 887-907). Thousand Oaks, CA: Sage.

Kemmis, S. \& McTaggart, R. (2005). Participatory action research: Communicative action and the public sphere." In N. K. Denzin \& Y. S. Lincoln (Eds.) Handbook of qualitative research (pp. 559-603). Thousand Oaks, CA: Sage.

Latour, B. (2004). Politics of nature: How to bring the sciences into democracy. Cambridge, MA: Harvard University Press.

Leggo, C. (2008). Narrative inquiry: Attending to the art of discourse. Language and Literacy, 10(1). Retrieved from: https://journals.library.ualberta.cal langandlit/index.php/langandlit/article/view/9770

Leavy, P. (2015). Method meets art: Arts-based research practice. New York: Guildford Press.

Manning, E. \& Massumi, B. (2014). Thought in the act: Passages in the ecology of experience. Minneapolis, MN: University of Minnesota Press. 
Massumi, B. (2011). Semblance and event: Activist philosophy and the occurrent arts. Cambridge, MA: MIT Press.

Metzger, D. (1992). Writing for your life: A guide and companion to the inner worlds. New York: Harper Collins.

O’Donohue, J. (2010). Four elements: Reflecting on nature. New York: Harmony Books.

Parry, D. C., Gover, T. D. \& Shinew, K. J. (2005). 'Mary, Mary quite contrary, how does your garden grow?': Examining gender roles and relations in community gardens. Leisure Studies, 24(2), 177-192. doi:

$10.1080 / 0261436052000308820$

Pink, S. (2009). Doing sensory ethnography. Singapore: Sage.

Prendergast, (2009). Introduction: The phenomena of poetry in research. In M. Prendergast, C. Leggo \& P. Sameshima (Eds.). Poetic inquiry: Vibrant voices in the social sciences (pp. xix-xlii). Rotterdam, NL: Sense.

Raisborough, J. \& Bhatti, M. (2007). Women's leisure and auto/biography: empowerment and resistance in the garden. Journal of Leisure Research, 39(3), 459-476.

Richardson, L. (1997). Skirting a pleated text: De-disciplining an academic life. Qualitative Inquiry, 3(3), 295-304.

Ryan, C. (2013). Playing with plants. Theatre Journal 65(3), 335-353. doi:10.1353/tj.2013.0069

Wang, C., \& Burris, M. A. (1997). Photovoice: Concept, methodology, and use for participatory needs assessment. Health Education \& Behavior, 24(3), 369387. doi:10.1177/109019819702400309

Weber, S. (2008). Visual images in research. In J. G. Knowles \& A. L. Cole (Eds.) Handbook of the arts in qualitative research (pp. 41-53). Thousand Oaks, CA: Sage.

Wendell, S. (1996). The rejected body: Feminist philosophical reflections on disability. New York: Routledge. 
Wolbring, G. (2013). Ecohealth through an ability studies and disability studies lens. In M. K. Gislason (Ed.) Ecological health: Society, ecology and health (pp. 91-107). London, UK: Emerald.

Zoetman, K. (1989). Gaiaosophy: The wisdom of the living earth. Hudson, NY: Lindisfarne Press. 